\title{
An intraoperative transesophageal echocardiography-guided maneuver to assist the removal of an intraventricular thrombus
}

\author{
Manobra intraoperatória guiada por ecocardiografia transesofágica para facilitar remoção de trombo \\ intraventricular
}

Edward GOLOGORSKY ${ }^{1}$, Enisa M CARVALHO ${ }^{2}$, Francisco Igor MACEDO ${ }^{3}$, Tomas SALERNO ${ }^{4}$

RBCCV 44205-1135

\begin{abstract}
Intra-cavitary thrombus size, mobility and friability are of great importance in deciding whether surgical removal is indicated. Thrombus characteristics may render surgical thrombectomy incomplete, a risk for catastrophic embolization. During de-airing of the heart, after removal of an intraventricular thrombus, filling the open ventricular cavity with blood serendipitously allowed trans-esophageal echocardiographic (TEE) visualization of undetected residual thrombi fragments. This experience leads us to advocate repeated filling and emptying of the left ventricle with blood, under TEE guidance, in order to facilitate complete removal of thrombotic material prior to ventriculotomy closure, and prior to weaning from cardiopulmonary bypass (CPB).
\end{abstract}

Descriptors: Embolism and thrombosis. Echocardiography, transesophageal. Echocardiography.

\section{INTRODUCTION}

Formation of intra-ventricular thrombus is common in the setting of acute myocardial infarction, non-ischemic cardiomyopathy, and hypercoagulable states, posing a challenge in management. Anticoagulation of the patient, with heart failure and mobile large thrombus, does not preclude its

\section{Resumo}

O tamanho, mobilidade e friabilidade do trombo intracavitário são de importância significativa na decisão para a realização da remoção cirúrgica. Precisamente, essas características do trombo podem resultar em uma trombectomia cirúrgica incompleta, com o risco de embolização catastrófica. Durante a manobra de deaeração após a remoção de um trombo intraventricular, o enchimento da cavidade ventricular com sangue permite a visualização de fragmentos residuais possivelmente indetectáveis. É proposto o enchimento e o esvaziamento repetitivo do coração com sangue guiado por ecocardiografia transesofágica intraoperatória para facilitar a remoção de material trombótico antes do fechamento da ventriculotomia e descontinuação circulação extracorpórea.

Descritores: Embolia e trombose. Ecocardiografia transesofagiana. Ecocardiografia.

fragmentation and embolization [1-3]. Similarly, surgical intervention may pose significant risk of re-mobilization of residual non-detected fragments. We, herein, report a surgical maneuver, using TEE surveillance, that allowed intra-operative detection of unsuspected fragmentation of a large mobile, balllike thrombus. The patient signed consent for the operation, also allowing use of this material for scientific purpose.

\footnotetext{
1. MD; Anesthesiologist.

2. MD; Researcher.

3. B.Sc.; Medical Student.

4. Professor-in-chief.
}

Work carried out in the University of Miami Miller School of Medicine and Jackson Memorial Hospital Division of Cardiothoracic Surgery and Department of Anesthesiology, Miami, United States
Correspondence address

Tomas A. Salerno, M.D. Jackson Memorial Hospital 1611 N. W. 12th Avenue Miami, Florida, 33139, United States of America Email: tsalerno@med.miami.edu 


\section{CASE REPORT}

A 65 year-old man presented to hospital with severe heart failure due to untreated tachycardia-induced nonischemic dilated cardiomyopathy (EF 12\%). TEE showed a left ventricular (LV) large mobile ball-like thrombus (Figure 1). Due to mobility and size of the mass, it was elected to remove it surgically. Normothermic CPB was instituted via cannulation of the ascending aorta, and the right atrium with a two-stage cannula. The heart was briefly fibrillated, and the apex was opened. A large mobile thrombus was removed, seemingly intact. Prior to ventriculotomy closure, de-airing of the LV ventricular cavity was performed, by filling the cavity with blood, by decreasing venous return to the heart lung machine.

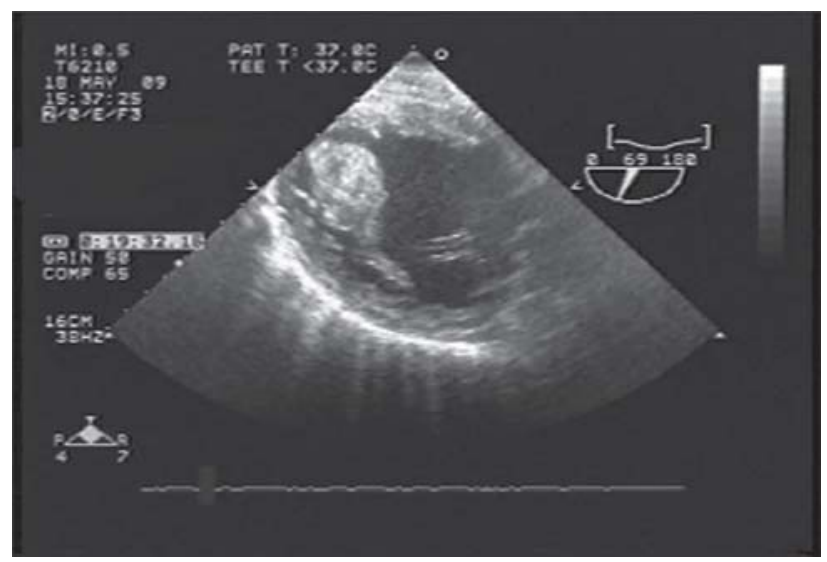

Fig. 1 - Transgastric long axis view shows the mass entrapped between papillary muscles

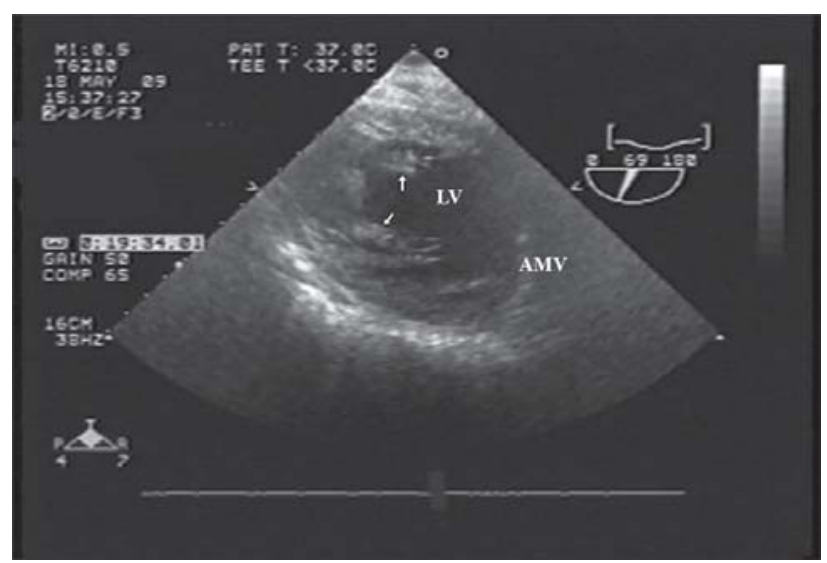

Fig. 2 - Thick strands of residual thrombotic material attached to chordae. Arrows point to residual thick fibrin strands, enmeshed in the chordae of the mitral valve. LV: left ventricle. AMV: anterior leaflet of mitral valve
Unexpectedly, residual fragments of thrombi material, lodged between the papillary muscles, were observed on TEE (Figure 2). These fragments were removed by repeatedly filling of the LV with blood and emptying it. This procedure was repeated until there was no further TEE evidence of thrombi in the ventricle. Intra-aortic balloon pump (IABP) was inserted due to very poor systolic function. The patient was extubated next day, and the IABP was removed. He made an uneventful recovery, with time-related improvement in ventricular function (EF 55\%), with restoration of sinus rhythm. He is well at 7 months follow up.

\section{DISCUSSION}

Intra-ventricular thrombus formation has been described in settings of cardiomyopathy (both ischemic and nonischemic), and in the presence of normal ventricular function in hypercoagulable states, such as anti-phospholipid syndrome [4]. Thrombi are described by location (apical and aneurysmal), natural history (recent (no organization) or chronic (organized or laminated), size (small, moderately sized, and large), shape (ball-like, protruding, or flat) and mobility [5]. There is always possibility of residual thrombi being left in the left ventricle or left atrium, regardless as to whether the heart is cardioplegically arrested or not. Even though anticoagulation in these patients decreases incidence of embolic events by $33 \%$, failure to surgically remove mobile or projectile thrombus, increase risks of systemic thromboembolization [6].

Moreover, fragmentation and embolization of intracavitary thrombi may lead to catastrophic outcome [6]. Thus, the ability to accurately detect, and describe intracavitary thrombi, is of paramount importance, especially perioperatively [7]. Most of these patients are effectively treated with anticoagulation. Surgery is reserved for large and mobile thrombi, which have high risk of fragmentation and embolization.

These characteristics make removal of thrombi from the left ventricle challenging. Not only visualization of the whole thrombus, through apical ventriculotomy, may be difficult but, during its removal, fragmentation may occur. This leads thrombi to be lodged between papillary muscles, as in this patient, or disloged into the left atrial cavity. Undetected, embolization may occur when the ventriculotomy is closed. Intra-operative TEE visualization of the intracavitary contents while the heart is open, is limited by presence of air. Alternatives to apical ventriculotomy, such as transaortic or trans-atrial routes, or video-assisted removal of thrombus, may be considered in the settings of non-friable, organized thrombus. Completeness of removal of residual fragments and fibrin strands, associated with fresh friable thrombotic mass, may be compromised. This leads to increased risk of peri-operative thromboembolic 
complications [8,9]. Serendipitously, we observed that by filling the LV cavity with blood prior to ventriculotomy closure, during de-airing of the heart, residual intra-cavitary fibrin strands and fragments could be visualized via TEE.

TEE provides objective means to ensure that all thrombi are removed. Limitation of the described technique rests in difficulty in TEE evaluation of LV intracavitary contents during open ventriculotomy. While TEE is considered the technique of choice, diagnostic pitfalls, such as thickened papillary muscles, chordae, aberrant tendons and thickened wall projections, may lead to false positive findings [10]. Most importantly, intracardiac air makes echo images impossible to interpret. However, by displacing air during de-airing maneuvers, by filling the heart with blood prior to ventriculotomy closure and careful assessment of intraventricular contents, improve TEE detection of residual thrombi fragments.

\section{REFERENCES}

1. Sharma ND, McCullough PA, Philbin EF, Weaver WD. Left ventricular thrombus and subsequent thromboembolism in patients with severe diastolic dysfunction. Chest. 2000;117(2):314-20.

2. Leeper NJ, Gupta A, Schnittger I, Wu JC. Clinical dilemmas in treating left ventricular thrombus. Int $\mathrm{J}$ Cardiol. 2007;114(3):e118-9.
3. Crawford TC, Smith 4th WT, Velazquez EJ, Taylor SM, Jollis JG, Kisslo J. Prognostic usefulness of left ventricular thrombus by echocardiography in dilated cardiomyopathy in predicting stroke, transient ischemic attack, and death. Am J Cardiol. 2004;93(4):500-3.

4. Plein D, Van Camp G, Efira A, Brunet A, Vandenbossche JL. Intracardiac thrombi associated with antiphospholipid antibodies. J Am Soc Echocardiogr. 1996;9(6):891-3.

5. Srichai MB, Junor C, Rodriguez LL, Stillman AE, Grimm RA, Lieber ML, et al. Clinical, imaging, and pathological characteristics of left ventricular thrombus: a comparison of contrast-enhanced magnetic resonance imaging, transthoracic echocardiography, and transesophageal echocardiography with surgical or pathological validation. Am Heart J. 2006;152(1):75-84.

6. Maslow A, Lowenstein E, Steriti J, Leckie R, Cohn W, Haering M. Left ventricular thrombi: intraoperative detection by transesophageal echocardiography and recognition of a source of post CABG embolic stroke: a case series. Anesthesiology. 1998;89(5):1257-62.

7. Sharma S, Ehsan A, Couper GS, Shernan SK, Wholey RM, Aranki SF. Unrecognized left ventricular thrombus during reoperative coronary artery bypass grafting. Ann Thor Surg. 2004;78(5):e79-80.

8. Connors CW, Locke A, Silver DA. Surgical approach to a left ventricular mass guided by transesophageal echocardiography. Anesth Analg. 2009;108(5):1465-6.

9. Kuh JH, Seo Y. Transatrial resection of a left ventricular thrombus after acute myocarditis. Heart Vessels. 2005;20(5):230-2.

10. D’Ancona G, Karamanoukian HL, Ricci M, Bergsland J, Salerno TA. Echocardiographic diagnosis of left ventricular density: diagnostic pitfalls. J Cardiothorac Vasc Anesth. 2001;15(3):394-5 